offers readers a wealth of individual perspectives on a rich and relevant history. Glasper's detailed biographical and oral historical work plunges the reader into anarcho punk's everyday existence, and in doing so, suggests with great clarity the ways in which popular culture operated as a critical site for the merging of politics and play. This is a book that should interest a wide range of readers, whether they are interested in punk's past, or in the dynamic history of anarchist politics and culture in the late twentieth century.

Eryk Martin

Simon Fraser University

\title{
Charlie Angus, Unlikely Radicals: The Story of the Adams Mine Dump War (Toronto: Between the Lines, 2013). 240 pp. \$24.95 Paperback.
}

In 2009, a group called the Post-Mining Alliance funded a book called 101 Things to do With a Hole in the Ground. The publication is beautifully illustrated and full of hopeful stories about former mines that have been converted to movie sets, football stadiums, cheese cellars, and research centres. One could debate whether such a publication (funded in part by industry) is selectively optimistic, and avoided the thousands of abandoned mines where problems with chemical pollution will persist for decades, or even eternity in some cases. But at least the book encourages creative design and land use options for those mines where remediation is possible. Nowhere does this publication suggest that using abandoned mines as garbage dumps is a smart thing to do with a hole in the ground.

But that is exactly what entrepreneur Gordon McGuinty and his company, Notre Development proposed to do with the abandoned Adams Mine near Kirkland Lake. A former iron mining operation owned by Dofasco Steel, the Adams Mine pits were slowly filling with water after abandonment, and exhibited no lasting pollution legacies after closure in 1989. McGuinty visited the south pit that year and thought it was an ideal location to park Toronto's massive garbage output after the planned closure of the Keele Valley landfill. Bob Rae's NDP government initially rejected the idea, but when McGuinty's North Bay associate Mike Harris became Premier in 1995, Notre Development (eventually aligned with a consortium of private interests called Rail Cycle North) and the provincial government effectively became co-proponents of the dump. Many residents of the Temiskaming district objected to the idea of taking Toronto's garbage, provoking a pitched fourteen year battle over the fate of the mine.

Charlie Angus' Unlikely Radicals is an eloquent first-hand account of the struggle against the Adams Mine dump proposal. Angus, currently a federal Member of Parliament with the NDP, is well-positioned to tell the tale, as he was a key leader in the protest movement. Indeed, the book is a stunning insiders' perspective on one of the most important environmental protests in the history of northern On- 
tario. An engaging and powerful story, Angus takes his readers to the front lines of the grassroots protest movement against the dump, recounting how ordinary citizens transformed themselves into accomplished activists in response to a significant environmental threat to their land. In broader terms, the book provides a fascinating case study of the kind of coalition politics that emerged so frequently during the Common Sense Revolution, in this case environmentalists, farmers, First Nations, general citizens, and political allies in Toronto all able to resist collectively the idea that northern Ontario's abandoned industrial landscapes could be used as a garbage dump.

The book also provides an important rebuttal to McGuinty's memoir Trashed, which almost hysterically labels the anti-dump protesters as environmental terrorists. Angus, by contrast, draws out the slow evolution of the movement from letter writing campaigns to decidedly non-violent road and rail blockades. He provides vivid memories of everything from the massive community meals to how tense moments with police were broken through close community ties (in one case protest leader Terry Graves managed to diffuse a standoff by striking up a conversation about roots singer Fred Eaglesmith with a local police officer). For anyone interested in the many factors (and quirky moments) that make a protest movement successful, Angus' book provides a valuable account about how to motivate and maintain a grassroots coalition in the face of massive and powerful external pressure.

More than a personal history of the protest movement, Unlikely Radicals also provides a strong indictment of the technical arguments in favour of the Adams' Mine dump proposal. Angus has a knack for boiling down complex technical debates, using plain language to strip away some of the bureaucratic language that often accompanies environmental reviews of these projects. He explains that, unlike purpose-built landfills, the Adams Mine would not have a reliable liner to contain contaminated water that might drain out of the site. Instead, the proponents relied on the concept of hydraulic containment, the theory that the mine would not leak from the mine because it could only flow in rather than out of the pits. The anti-dump coalition managed to mobilize independent experts, with university-based experts suggesting that the mine would indeed leak, and that the proposal to treat contaminated water for only 100 years was unrealistic because modern garbage can be a source of pollution for ten times that amount of time. Even if the Ministry of the Environment approved the project in a split decision in 1998, Angus' account of the process provides a valuable insight into the way environmental assessment processes sometimes ram projects through based on the advice of consulting firms who have every interest in keeping the project proponents (i.e., the customer) satisfied.

Unlikely Radicals is not a scholarly book, nor was it intended to be. However, Angus does, to his credit, contextualize the Adams Mine protest in terms of the environmental justice movement (which revolves around the idea that hazardous 
waste sites are disproportionately situated next to communities comprised of racial minorities or the poor) and the more recent concept of sacrifice zones (areas that are severely degraded with pollution to serve the interests of industry with no regard for the people that live there). Herein lies my only complaint: Angus could have provided a bit more of a comparative dimension to the book, analyzing how the Adams Mine fight fits with, or is distinct from, other well-documented struggles against toxic waste dumping throughout North America. This is a minor quibble, however, as Angus' story is hardly narrow in scope. His account of the Adams Mine controversy is fascinating and significant, bound to hold any reader with an interest in environmental politics, protest movements, or waste management issues.

John Sandlos
Memorial University of Newfoundland

\section{Stephen Azzi, Reconcilable Differences: $A$ History of Canada-US Relations (Oxford University Press, 2014). 320 pp. \$62.95 Paperback.}

Stephen Azzi's Reconcilable Differences: A History of Canada-US Relations grapples with the evolving relationship between Canada and the United States from the beginning of the American Revolution through to the present-day. Azzi focuses on some of the parallel social and cultural movements throughout the period. By directing the reader towards a number of political, economic, and military realities, Reconcilable Differences offers a concise account of Canadian-American relations.

As Azzi explains in his preface, four ideas provide the backbone to his study. Azzi contends that the Canada-US border has always been fluid and that the border itself did not stop the free movement of people and ideas for much of their history. As such, Azzi asserts that to understand the histories of these two distinct countries individually requires a background of them both. Azzi sees the CanadianAmerican relationship differently from region to region. For example, Azzi explains that while Canada and the United States were warring in the Niagara peninsula from 1812 to 1814, residents of New Brunswick and Maine experienced a relatively peaceful relationship with no fighting in the area. Crucially, however, Reconcilable Differences sees the Canadian-American relationship as complex and not easily explained; there is neither one rule nor practice that defines the widely varying or similar intricacies of this relationship. Finally, while Azzi acknowledges that political developments are critical to understanding Canada-US relations, other factors must be considered to uncover the dynamic ways in which this relationship has evolved.

Despite acknowledging that Canadians often identify themselves as "not American" or "better than American," Azzi asserts that the similarities between Canada and the United States far outweigh these sentiments. (261) He argues that the Loyalists who came to British North America in the wake of the American Revolution were far more American than British. Consequently, loyalist identity was mytholo- 